\title{
Studies on the specificity of adrenocortical function in ruminant nutrition
}

III. Effect of season, age and sex on plasma adrenocorticoids level of cattle, sheep and rats

\author{
Yoshiyuki Sasakr,* Taiji Dôgo, Ryôji Kawashrma \\ and Shôji UESAKA \\ (Laboratory of Zootechnical Science, College of \\ Agriculture, Kyôto University, Kyôto)
}

(Received for Publication on December 17, 1970)

Adrenal weights and adrenocorticoids (11-OHCS) levels in plasma and adrenal tissues, in several domestic and laboratory animals, were presented in our previous paper together with the ratio of cortisol to corticosterone ${ }^{4}$. . For proper evaluation of these results, possible effects of season, sex and age on these parameters should be taken into consideration. Among a few available reports, PATERson ${ }^{8 /}$ described that plasma 11-OHCS levels in cattle were influenced by seasons, and WATANABE ${ }^{B)}$ reported that similar tendency exists in humans. For the effect of age, SHAw et al. ${ }^{6}{ }_{1}$ reported that plasma 11-OHCS levels of calves, three to eight months old, were similar to those of adult cows.

Sexual difference in plasma $11-\mathrm{OHCS}$ is apparent in mature rats ${ }^{1,21}$, but that in sheep or in cattle has rarely been reported.

The purpose of this study is to elucidate effects of age, sex and season on the plasma 11-OHCS levels of cattle, sheep and rats.

\section{Materials and Methods}

The breed and the number of animals used in this study are presented in Table 1. Cattle were fed at Tottori Livestock Breeding Station** and Department of Animal Industry, Chûgoku Agricultural Experimental Station**. Sheep were fed at Chûgoku Livestock Breeding Station**. Rats were fed at our laboratory, and they were moved into individual cages 10 days before starting each experiment. The animals consisted of both sexes of various ages.

Table 1. The breed and the number of animals

\begin{tabular}{llccc}
\hline \multirow{2}{*}{ Species } & \multicolumn{1}{c}{ Breed } & \multicolumn{3}{c}{ Number (heads) } \\
\cline { 3 - 5 } & & Male & Female & Total \\
\hline Cattle & Japanese Black & 67 & 140 & 207 \\
Sheep & Japanese Corriedale & 54 & 71 & 125 \\
Rat & Wistar & 24 & 22 & 46 \\
\hline
\end{tabular}

\footnotetext{
* : Present address: Laboratory of Animal Breeding, Faculty of Agriculture, Miyazaki University, Miyazaki

**: All these stations belong to Ministry of Agriculture and Forestry of Japan
} 
The seasons tested were early summer (June, 1969) and late winter (February, 1970).

Blood samples were obtained from the jugular vein in cattle and sheep, and from the cervical artery in rats. Heparin sodium was added as an anticoagulant. According to $\mathrm{Z}_{\mathrm{IM}}$ MERMAN $e t a l .^{0}$, it takes several minutes for rats to show the response of plasma corticoids level after being exposed to stress. The blood samples in the present study seemed to be of "resting conditions", since the time required for handling and bleeding was less than one minute.

Blood was usually drawn under stress-free conditions late in the morning. The blood sample was centrifuged and the supernatant plasma was stored at $-15^{\circ} \mathrm{C}$ until analysis.

The determination of 11-OHCS in plasma was carried out by the method described in our previous paper ${ }^{5}$. The outline is as follows: The plasma was first washed with the three volumes of petroleum ether, then it was extracted with the five volumes of methylene chloride. This extract was re-washed with the $1 / 15$ volume of $0.1 \mathrm{~N}$ sodium hydroxide and re-extracted with $75 \%$ ethanolic-sulfuric acid solution. The fluorescence of this re-extract was measured with Shimazu-Kotaki microfluorometer.

\section{Results and Discussion}

Plasma 11-OHCS levels of male and female animals in early summer and late winter are shown in Table 2. It was observed in this study that plasma 11-OHCS levels of cattle and sheep were quite low as compared to those of rats, regardless of seasons and sexes; this agrees well with our previous report ${ }^{4}$ ).

Plasma 11-OHCS levels of cattle and sheep in winter seemed to be similar to those in summer, while the levels of rats in winter had a tendency to be higher than those in summer though the difference was not significant.

In cattle and rats, plasma 11-OHCS levels of the female seemed to be higher than those of the male. The sexual difference was obvious in the case of cattle in summer $(P<0.01)$ and rats in winter $(P<0.05)$. Effects of sex were obscure in sheep, though the levels of the male seemed to be somewhat higher than those of the female.

Values of plasma 11-OHCS in Table 2 were further classified into several groups according to the age as shown in Tables 3,4 and 5 , to facilitate the analysis of possible effects of sex and season.

Plasma 11-OHCS levels of cattle of both sexes, seven to twelve months of age, were higher in winter than those in summer, but this seasonal difference was significant only in

Table 2. Sexual and seasonal differences in plasma 11-OHCS levels of cattle, sheep and rats

\begin{tabular}{llcc}
\hline \multirow{2}{*}{ Species } & \multirow{2}{*}{ Season } & \multicolumn{2}{c}{ Plasma 11-OHCS level $(\mu \mathrm{g} / 100 \mathrm{~m} l)$} \\
\cline { 2 - 4 } & & \multicolumn{1}{c}{ Male } & Female \\
\hline \multirow{2}{*}{ Cattle } & Summer & $1.47^{a} \pm 0.49(30)^{*}$ & $1.81^{a} \pm 0.85(69)$ \\
& Winter & $1.66 \pm 0.76(37)$ & $1.77 \pm 0.94(71)$ \\
\multirow{2}{*}{ Sheep } & Summer & $3.05 \pm 1.06(30)$ & $2.78 \pm 0.96(34)$ \\
& Winter & $3.27 \pm 1.40(24)$ & $3.02 \pm 1.19(37)$ \\
Rat & Summer & $26.98 \pm 21.29(14)$ & $39.72 \pm 30.19(12)$ \\
& Winter & $36.95^{b} \pm 12.11(10)$ & $52.03^{b} \pm 36.60(10)$ \\
\hline
\end{tabular}

$a$ and $b$ : Means having a common letter in their superscripts are statistically different $(P<0.05)$

* : Meantstandard deviation; The number of observations is indicated in parentheses 
Effect of season, age and sex on plasma 11-OHCS level
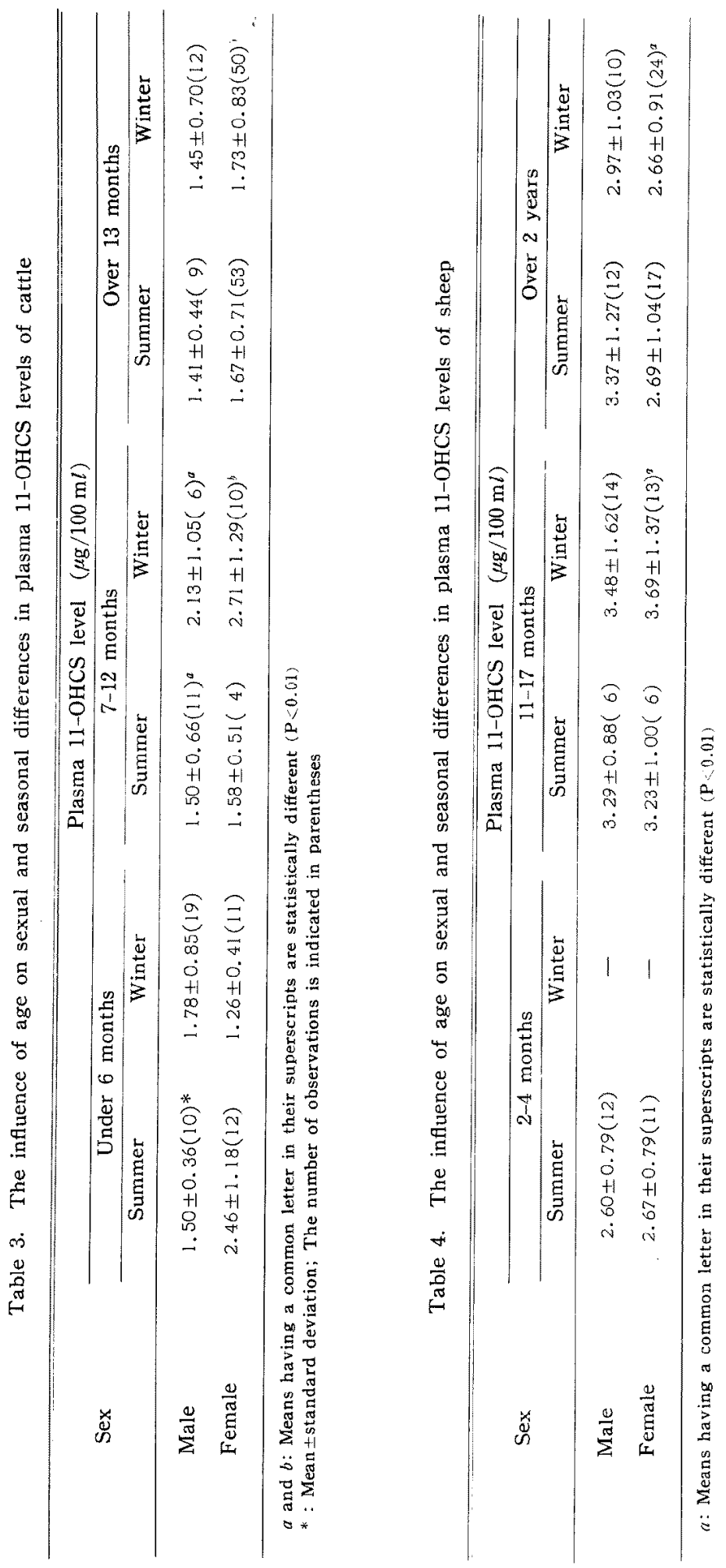
Sasaki - Dógo - Kawashima - Uesaka

Table 5. The infuence of age on sexual and seasonal differences in plasma 11-OHCS levels of rats

\begin{tabular}{llll}
\multirow{2}{*}{ Age } & & \multicolumn{2}{c}{ Plasma 11-OHCS level $(\mu \mathrm{g} / 100 \mathrm{~m} l)$} \\
\cline { 3 - 4 } & & Meason & Female \\
\hline \multirow{2}{*}{ Old } & Winter & $41.7(2)^{a)}$ & $18.1(2)$ \\
\multirow{2}{*}{ Middle } & Summer & $25.2(5)$ & $45.1(5)$ \\
& Winter & $32.3(3)$ & $54.4(3)$ \\
Young & Summer & $22.0(6)$ & $34.3(5)$ \\
\multirow{2}{*}{ Suckling } & Winter & $37.8(5)$ & $64.1(5)$ \\
& Summer & $39.9(3)$ & $40.0(2)$ \\
\hline
\end{tabular}

a): Number in the parentheses shows the number of samples

the male $(P<0.01)$. Seasonal effects in younger and older ages were not significant.

In sheep, age did not affect the sexual and seasonal difference of plasma 11-OHCS levels except in the females of older than 5 years in which there was a gradual decrease with age.

In rats, data obtained were limited. Only conclusion that can be deduced may be that the plasma 11-OHCS levels in this species are readily affected by the season, high in the winter and low in the summer. Effect of sex was obvious only in the adult. CRITCHLow et al.1) reported the similar resnlts.

Whether the marked difference in plasma 11-OHCS levels between the ruminants and rats is mere reflection of the body size or tied up with their metabolic pattern awaits further elucidation. It is interesting that plasma 11-OHCS levels in cattle are fairly stable except an age range of seven to twelve months. This is a range in which calves are susceptible to Kiriyoi disease ${ }^{7)}$, and hence adrenal dysfunction could be involved in its etiology.

\section{Summary}

In order to elucidate the influence of season, sex and age on plasma 11-OHCS levels, blood samples of cattle, sheep and rats collected during early summer or late winter were analyzed. The animals used, consisted of both sexes of various ages in each species. The results obtained are as follows;

1) Plasma 11-OHCS levels of cattle and sheep were lower than those of rats regardless of seasons and sexes.

2) Plasma 11-OHCS levels of the female were higher than those of the male in cattle and rats, while sexual difference was obscure in sheep.

3) In calves seven to twelve months of age, plasma 11-OHCS levels were high in winter and low in summer. Similar seasonal effect was observed in rats, but not in sheep.

4) Influence of age on plasma 11-OHCS levels was appreciable in sheep and rats.

\section{Acknowledgement}

The assistance of Tottori Livestock Breeding Station of Ministry of Agriculture and Forestry of Japan; Department of Animal Industry, Chûgoku Agricultural Experimental Station and Chûgoku Livestock Breeding Station of Ministry of Agriculture and Foreștry of Japan in taking blood samples for this study is greatly appreciated. 


\section{References}

1) Critchlow, V., R. A. Liebelt, M. Bar-Sela, W. Mountcastle and H. S. Lipscomb (1963) Amer. J. Physiol., 205: 807-815.

2) Gala, R. R. and U. Westphal (1965) Endocrinology, $77: 841-851$.

3) Paterson, J. Y.F. (1957) J. Comp. Path., 67: 165-179.

4) SASAKI, Y., T. Dôgo, R. Kawashima and S. UesaKa (1971) Jap. J. Zootech. Sci., 42: $142-148$.

5) Sasaki, Y., R. Kawashima and S. Ubsaka (1970) Jap. J. Zootech. Sci., 41: 632-641.

6) Shaw, K.E. and R.E. Nichols (1962) Amer. J. Vet. Res., 23: 1217-1218.

7) Sugano, S. (1947) Jap. J. Vet. Sci., 9: 163-169.

8) Watanabe, G. (1964) Arch. Environ. Health, 9: 192-200.

9) Zimmerman, E. and V. Critchlow (1967) Proc. Soc. Exptl. Biol. Med., 125: 658-662.

\section{副腎皮質機能の反蜀動物栄養に和ける特異性に}

関する研究

III. ウシヒッジ，ラットにおける血墏中副腎度質ホルモン濃度に

及ぼす季節，年令，性の影響について

佐々木義之*・道後泰治・川島定治・上坂章次

(京都大学:農兴覀)

本笑験は季節，年令，性の血獎中副腎攴質ホルモン (以下 11-OHCS と略す) 浱度に及ぼす影響について調 べとくにこの点において動物の種による差異があるか どうかを検討した．実験に用いた動物はウシ。ヒッジ， ラットであり，各々雌雄方よびいろいろの年令のもの定 含んでいた，比較を行なった季節は初夏と晚冬であっ た.

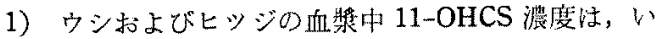
ずれの場合もラットに㧍けるその濃度より低かった。

2）ウシ招よびラットに括ける血漿中 11-OHCS 濃儤

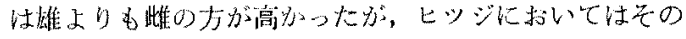
差法明らかでなかった。

3）血漿中 11-OHCS 㶇度の季節㴽はウシでは, 7〜

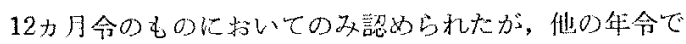
は，こ机法認められなかった。ヒッジの場合は，いずれ の年令に打いてもこの季節差は認如ら机なかった。 ラッ トではこの差は顕著であり，夏よりも冬の方が高か。 t.

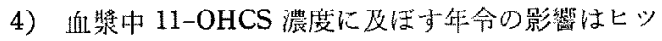
ジ拉よびラットで，いくぶ兀哂められた。

* 現在・宮畸大学掌部 